\title{
Error Analysis in EFL Writing Classroom
}

\author{
Abdul Karim ${ }^{1}$, Abdul R. Mohamed ${ }^{1}$, Shaik A. M. M. Ismail ${ }^{1}$, Faheem H. Shahed ${ }^{2}$, Mohammad Mosiur Rahman ${ }^{3}$ \\ \& Md. Hamidul Haque ${ }^{4}$ \\ ${ }^{1}$ School of Educational Studies, Universiti Sains Malaysia, Penang, Malaysia \\ ${ }^{2}$ BRAC Institute of Languages, BRAC University, Dhaka, Bangladesh \\ ${ }^{3}$ School of Languages, Literacies and Translation, Universiti Sains Malaysia, Penang, Malaysia \\ ${ }^{4}$ Department of English, American International University, Dhaka, Bangladesh \\ Correspondence: Abdul Karim, School of Educational Studies, Universiti Sains Malaysia, Penang, Malaysia. \\ E-mail: khasan13aiub@gmail.com
}

Received: February 5, 2018 Accepted: March 6, 2018 Online Published: March 22, 2018

doi:10.5539/ijel.v8n4p122 URL: https://doi.org/10.5539/ijel.v8n4p122

\begin{abstract}
Identifying the EFL learners' errors in writing has no longer been important but essential. As such, drawing the pertinent questions that what are the most common types of error committed by EFL learners in Bangladesh and what are the perceptions possessed by them concerning error correction, the article addressed the commonest errors committed by the learners and the perceptions of them toward error correction. Additionally, adopting the error analysis suggested by Ellis, the categorical presentation of the errors was also accomplished. This study comprised a corpus of EFL learners in the secondary level to enquire the commonest errors. Along with this, a student survey was carried out to reveal the perceptions of the students regarding error correction. The common errors identified were subjected to, grammar, misinformation, misordering and overgeneralization. Additionally, the study uncovered strong preference of the EFL learners to get their errors to be corrected by the teachers.
\end{abstract}

Keywords: error correction, error analysis, EFL learner, perception, EFL writing

\section{Introduction}

Concerning error correction in the writing classroom, scholars have been found to conceive two schools of thought. Actually, past few decades have been the years of constant debate concerning whether or not students' errors should be corrected by the teachers. Consequently, the researchers of early 1980s or 1990s seemed to be strong opponents of error correction, given that their studies uncovered no effect of corrective feedback (CF) on second language learners. For example, Cohen \& Bobbin's (1976) findings indicate that "the correction did not seem to have any significant effect on students' errors" (p. 50). Subsequently, as regards grammar correction, Truscott (1996) argued that it is ineffective, releasing drastic effects on the pupils. Building on Semeke (1984), VanPatten (1986) and Leki's (1990) findings, Truscott belittles the importance of error correction for L2 learners. He holds the view that accuracy can be achieved "through extensive experience with the target language - experience in reading and writing" (p. 360). However, the later studies reveal significant impact of (CF) on building learners' accuracy. In particular, Bitchener's (2008) experiment uncovers that CF substantiates learners' accuracy. He concludes that CF is inevitable in L2 writing class. According to Sung \& Tsai (2014) CF facilitates learners to relate form and meaning to communication which ultimately leads to second language acquisition. Wang (2017) identifies providing feedback for students' writing as one of the core responsibilities of language teachers. It is perceived beneficial for the learners since it concerns whether they are good writers or whether the pedagogical practices fulfill students' expectations of instruction. Coupled with this is the critical information catered by Corrective feedback which conveys indispensable information to the students regarding their writing performance; consequently, leading students to become critical and proficient L2 writers. Ferris (2010), however, elucidates the paucity of empirical research on corrective feedback in L2 writing before the mid-1990s, preceded by the historical and theoretical trends. One of the influential factors concerning this is Krashen's SLA theory $(1981,1982, \& 1985)$ which at that time devalued corrective feedback in writing instruction. It was not until 1990, when researchers started penetration addressing language issues in L2 writing, supporting "the idea that error correction should be contextualized within the writing process prioritized to focus on the most frequent and serious errors and should pay attention to individual learners' needs in writing" (p. 74). 
Nevertheless, researchers repeatedly suggested that error correction is ineffective for improving pupils' writing (Cohen \& Robbins, 1976; Polio, Fleck \& Leder, 1998; Robb, Ross \& Shortreed, 1986; Truscott, 1996); however, there is no denying fact that due to lack of writing teachers' feedback students become frustrated (Lee, 2004). It is evident that L2 students demand their errors to be notified by the teachers, believing that such feedback will be beneficial for them (Leki, 1991; Radecki \& Swales, 1988). Thus, proponents of error correction argue that teachers should elicit students' errors. It is also noteworthy that proper categorization of learners' errors should be identified so that students can get aware of which areas to be improved, given learners' errors can be different. For instance, errors can arise from grammar, omission, misinformation and misordering, which, in what follows, the article has elaborated on. If the teachers specify errors categorically, it would be easier for the learners to correct their errors quickly. Although numerous studies have been undertaken in relation to learners' errors, the current study is unique in that it incorporates the categorization of errors, which will potentially inform EEL teachers to address the areas of improvement for their pupils. This study, meticulously, intends to identify the common types of error committed by the secondary-school learners in writing class. In addition, this study also aims at uncovering the students' perspective subjected to error correction.

\subsection{Conceptualization of Learners' Errors, Error Correction and Error Analysis}

To educators and researchers, errors occur naturally in the process of language learning (see Edge, 1989; Hendrickson, 1987). Learners' errors particularly the ones committed in writing are identified as the key interest of teachers, linguists and syllabus designers (Darus \& Ching, 2009; Katayama, 2007b). Corder (1967) compartmentalizes the thoughts conceived by educators regarding learners' errors. The first group of thinkers perceives that the learners' errors notify the insufficiency prevailing in teaching. In contrast, another group of educators see errors resulted from the imperfect world we live in. According to Corder (1967), errors are systematic, consistent and deviant characteristics of learners' linguistic system at a certain phase of development. Dulay, Burt \& Krashen (1982) define error as: "the flawed side of the learner's speech or writing. They are those parts of conversation or composition that deviates from selected norm of mature language performance" (p. 138).

Error correction subsumes dual meaning since it is sometimes carried out spontaneously by the teachers and sometimes it is done due to appeal of the learners to correct the erroneous part (Lee, 2004). On one hand, it means the feedback generally yielded by the teachers on pupils' errors, and on other hand, it refers to the correction suggested by the teachers on learners' errors. Lee (2004) identifies the latter one as specific type of error feedback strategy. Such distinction is portrayed on this article since it concerns the error corrections provided by the teachers for the learners. In other word, it can be referred as overt correction of learners' errors (Lee, 2004). Study carried out by Hedgcock \& Lefkowitz (1994) shows that foreign language learners opt for the grammatical correction given by the teachers. Moreover, studies, e.g., Cohen \& Cavalcanti (1990) and Ferris et al. (2000), also show that learners prefer their errors to be corrected by the teachers. There is a diversity prevailing in learners' preferences of error correction. Some learners tend to be corrected by self while others prefer it to be done by peers or teachers. Below are the types of error corrections delineated by Omaggio (1986):

- Peer correction: Teachers ask pupils to check each others' scripts interchangeably. Teachers' also encourage the students to deliver feedback on the scripts they have gone through.

- Self correction: It is the best way to approach to correct what has been written. Pupils take the responsibility to correct their own errors.

- Teacher correction: Teachers provide learners with correct answers.

Error analysis is defined as the technique for identifying, classifying, and systematically interpreting the unacceptable forms produced by a learner of a foreign language. Such analysis informs learners' errors, and thereby, notifies the competence learners attained (Sinha, 1997). Researchers perceive errors as a part of error analysis. Error analysis, as Corder (1974) illustrates, is done to identify learners' areas of opportunities. He calls for certain steps to be followed during the analysis of errors. These entail the collection of a sample of learner language, identification of errors, description of errors, explanation of errors and evaluation of errors. For error analysis, Ellis (2002) also suggests similar stages to follow. This study adapts the procedures suggested by Ellis to carry out the error analysis. The underpinning reason for choosing it is that, in Ellis' elicitation the errors are presented categorically. It not just subsumes the grammatical errors but it also includes the errors resulted from omission, misinformation and misordering. As such, the holistic identification of learners' errors can be revealed. Furthermore, the distinction between error and mistake has been drawn blatantly here. As such, it is easier for us to define the erroneous part either as error or mistake. If the teachers are cognizant about which one is error and which one is mistake, it becomes easier for them to address the problems associated with students' writing.

At the beginning of all is identifying the errors in which the errors made by the learners are identified for 
analysis. For identifying the errors, the sentences written by the learners have to be compared with "what seem to be normal or correct in the target language" (p. 16). Although, as he mentions, it becomes difficult to reconstruct the correct sentence since the meaning writer wants to deliver is not certain. Besides, identifying the errors committed by the learners is often challenging because it is difficult to distinguish between errors and mistakes. Thus, he also differentiates errors and mistakes. Errors result from lack of learners' knowledge (Ellis, 2002). Learners do not know the correct one, and thus, make errors, he explicates. Mistakes, on the other hand, refer to the "occasional lapses in performance; they occur because, in a particular instance, the learner is unable to perform what he or she knows" (p. 17). Ellis (2002) also clarifies that depending on the consistency of learners' substitution of one instead of another, the errors and mistakes can be identified. However, if learners are seen using the correct form in their writing, and at some point, they use the incorrect form, Ellis (2002) suggests to consider it as mistake.

The next step in error analysis, according to Ellis, is describing errors. He calls for categorizing the errors into different parts, such as, verb errors, omission, misinformation and misordering, According to him, errors related to verbs are considered as verb errors. Missing to state one item required for a particular utterance is known as omission. Substituting one grammatical structure with another is claimed as misinformation while placing words wrongly is known as misordering. Ellis expounds, such compartmentalization of errors can facilitate a plausible diagnosis of learners' learning problems. The following stage is the explanation of errors. There are some errors which are the result of learners' own rule, which is different from that of English (Ellis, 2002). Besides, some errors are universal, meaning that in the certain stage of the language learning process, learners tend to substitute one grammatical form with another. In addition, there are some errors existing in the writing of learners sharing same native language (L1). Another error learners make is overgeneralization. Such error occurs due to the learning process of the learners. Finally, when L1 interference takes place, the error-transfer-occurs.

The final task, according to (Ellis, 2002), is the evaluation of learners' errors. He identifies some errors as global ones, breaking the overall structure of the sentence. Thus, readers cannot process the sentence. Local errors, another type of errors, that "affect only a single constituent of the sentence, and are perhaps, less likely to create any processing problem" (p. 20).

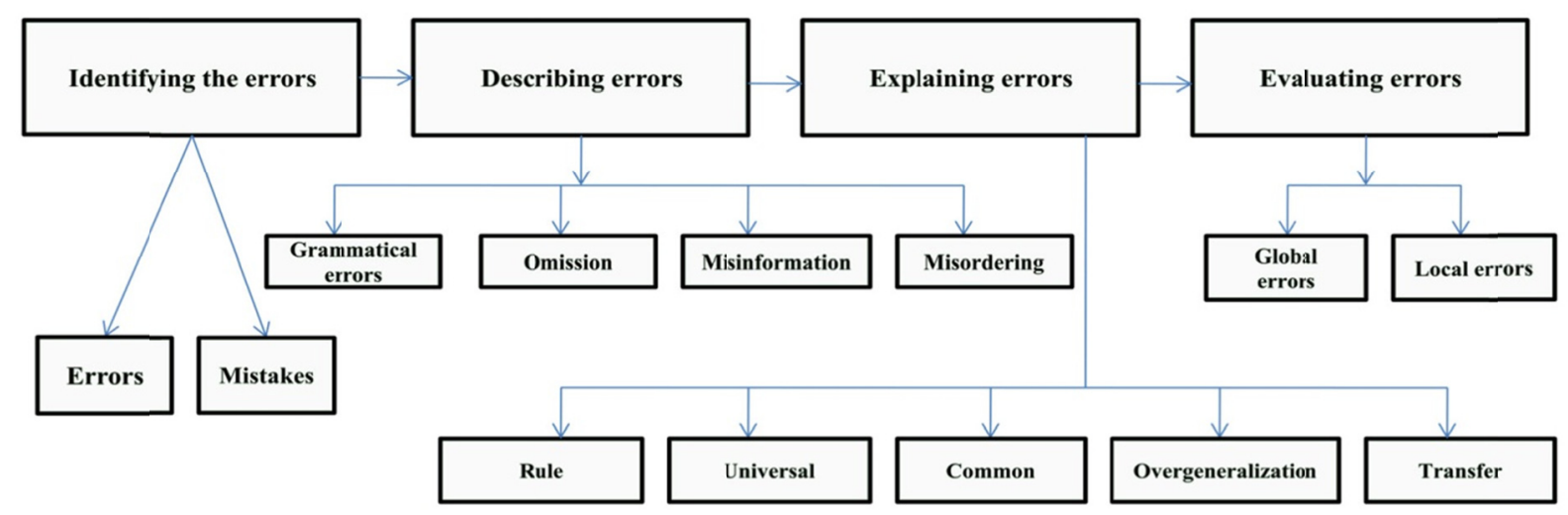

Figure 1. Analysis of error (Ellis, 2002)

\section{Method}

\subsection{The Context}

Bangladesh belongs to EFL contexts (Chowdhury \& Kabir, 2014). Ali \& Walker (2014) corroborate this explaining that the nation is commensurate with the characteristics of EFL contexts. Nunan \& Carter (2001) defined that a context is considered as EFL one, if English language gets exposed to classroom only. The education system in Bangladesh is consisted of three tiers (Ali \& Walker, 2014). These are mainstream or the secular state education, Madrasha education (religious education) and English-medium education. Bangladesh Bureau of Educational Information and Statistics (BANBEIS) reports that primary, secondary and higher secondary levels comprise mainstream education. Grade 1-5 is considered as primary level. Grade 6-10 constitutes secondary level while Grade 11-12 comprises higher secondary level. Bangladesh adopts dynamic and ambitious ELT policies. English is acknowledged as a compulsory subject to study from Grade 1 to 12 in the national curriculum (Hamid \& Honan, 2012). 
It is noteworthy that Bangladesh has integrated English for Everyone (EFE) policy that facilitates language learning opportunity for learners irrespective of their socio-economic statuses and geographic locations. In Bangladesh, English is mandated as an academic subject (Ali \& Walker, 2014). English for General Purposes (EGP) precedes the English Language Teaching (ELT) in this state, they illustrate. However, in all grades, other subjects, apart from English, are taught in Bengali, the native language. Learners, as such, solely depend on the subject English to learn English. In the primary level, there are six classes every day, in which each consists of 40 minutes except the first one with 55-minute duration. Similarly, in the secondary level, students have six classes every day in which each lasts for 40 minutes with 55 minute for the first one. Learners in all levels have English class every day. It is conspicuous that students can avail approximately four hours weekly to learn English in Bangladesh, given the books of the remaining subjects are written and taught in Bengali. Such policy integrated by the curriculum curtails the exposure to English outside the classroom. The time weekly allocated to learn other subjects in Bengali is almost six times as much as that provided for English.

Bangladeshi learners traditionally struggle to attain English language skills; even after 12 years of schooling and four years of tertiary education, most of the learners fail to equip with necessary language skill (Hamid, 2010). In other EFL contexts similar to Bangladesh, researchers have identified writing as the most obligatory but complex skill for learners to attain, amid four language skills (see Darus \& Ching, 2009). Being competent in writing skill enables learners' pragmatic expression. Furthermore, a good command in writing using English opens diversified avenues for the learners to be employed in the prestigious-corporate world (Darus \& Ching, 2009). However, the recognition as an EFL context and little exposure to English result in erroneous writing of Bangladeshi learners (Hasan \& Akhand, 2010). Deplorably, very few studies have been conducted to identify the common errors occurred usually in Bangladeshi learners' writing. Consequently, the errors committed by the Bangladeshi students have never been analyzed categorically. On top of that, no study has been carried out to identify the perception of the Bangladeshi learners regarding the error corrections suggested by the teachers. This study, particularly, aims at answering the following questions:

- What are the most common types of errors committed by the EFL learners in Bangladesh? What are the categories of the errors?

- What are the perceptions of the students regarding error corrections suggested by the teachers?

\subsection{Research Instrument}

The corpus harnessed in this study was a subcorpus comprising a larger corpus of argumentative essays, preceded by the International Corpus of Learner English (ICLE) (Granger, Dagneaux \& Meunier, 2002) written by grade 9 and 10 students (aged between 15 and 16) belonged to three secondary schools (Bengali medium) in Bangladesh. The subcorpus, entitled the EFL learner Corpus, included 70 essays containing 21700 words (average 310 words in each essay) written by the students, given their mother tongue was Bengali. The participants belonged to the same socio-economic status. They belonged to six urban-government secondary schools, in which students of middle class family usually admit for their schooling. They have to pay only a little amount of money as their yearly fees. Therefore, we considered them as the members of the same socio-economic status. The essays were word-processed, and students were asked to submit them as a typical class-assignment. They were not asked to submit their writings within a stipulated time-period. Availing the freedom, students completed their writings and submitted them in their own time. It is worth mentioning that the English proficiency level of the participants did not noticeably vary since they belonged to grade 9 and 10 . The data was collected after the completion of their first terminal examination, provided there are two examinations students have to appear yearly. We asked them to write the scores they had obtained in English in the first terminal examination. It was observed that their scores did not vary noticeably, given their marks ranged from 60 to 70 out of 100. Accordingly, we considered them having similar level of English proficiency. They were exposed to basic grammatical rules by grade 7 and 8 . By grade 7 and 8 , students were introduced to grammatical components including parts of speech, nouns, verbs, possessives, articles, sentences, adjectives, adverb, prepositions, linking words, modal, tenses, and so on. In grade 9, students were introduced to voice, conditionals, speech, tag questions and sentence connectors. These components are introduced to them before their first terminal examination. This study was carried out after this examination. Accordingly, all the new components had been taught, and they were left with nothing to be introduced. In Appendix B, the grammatical syllabi for grade, 7, 8, 9 and 10 were briefly presented. Answering the second research question required students' survey questionnaire (Appendix A) developed bilingually (in both Bengali and English). Lee (2004) harnessed this questionnaire to reveal students' perceptions, beliefs, and attitudes regarding error correction. The current study adapted this questionnaire since it addressed the points demanded by it. This questionnaire was designed based on a literature review derived from previously conducted studies incorporating student errors and teacher 
feedback, perceiving that it would yield information on students' perception, beliefs, and attitudes concerning error correction. Both versions (Bengali and English) were pretested and revised by two graduate research students to secure the proper translation. Finally, the one in Bengali was employed in this study. The administered questionnaire included statements about their teachers' error correction practices as well as participants' own beliefs and attitudes about error correction. We administered follow-up interviews, in which participants had elaborated on some of the questionnaire statements. In addition, we conducted the interview by informing the interviewees that their elicitations will be published, and after securing their consent we incorporated their expressions. We also maintained anonymity throughout the data presentation process.

\subsection{Sample}

Following convenience sampling, the students to respond to the questionnaire were selected. This study adopted convenience sampling because, according to Gay, Mills \& Airasian (2011), such sampling provides the researchers with the participants depending on their availability. The survey questionnaires were sent to six schools. A contact teacher in each school was held responsible for distributing the questionnaires to the students. Three-hundred students finally participated in this study from six schools. It is noteworthy that 155 participants belonged to grade 9 and 145 participants from grade 10 were selected to complete the questionnaires. Participants for the interview session were selected espousing purposive sampling. According to Gay et al. (2011), purposive sampling offers samples that are considered representative of a given population. As such, 20 participants were selected to take part in follow-up interview.

\subsection{Data Analysis}

The students' writings were checked by two English teacher educators to identify the errors. The errors identified in the first phase were categorically subjected to SPSS analysis, generating descriptive data (Table 1). Subsequently, adopting the error analysis process suggested by Ellis (2002), the categorical presentation of the errors was accomplished (Figure 3). Data elicited from student questionnaire survey were also subjected to SPSS analysis, yielding descriptive data mainly (Tables 5, 6, 7, 8, 9). Data derived from student interview were translated from Bengali to English. Then, these are transcribed, summarized and categorized. Fourth and fifth authors were assigned to accomplish translation and transcription work. They were thought eligible to carry out this task because they had been teacher educators, and they conducted translation studies, a MA in TESOL course, in two universities.

\section{Results}

Our current study had aimed at answering the following questions:

- What are the most common types of errors committed by the EFL learners in Bangladesh? What are the categories of the errors?

- What are the perceptions of the students regarding error corrections suggested by the teachers?

The results of the study are presented below under the heading of these two questions.

\subsection{Research Question No 1}

The first research question was intended to reveal the most common types of errors committed by the EFL learners in Bangladesh and present a category of the error. From the samples, different types of errors were identified, which are presented categorically in the following parts of this section. As mentioned earlier, the current study adapts the errors and error analysis suggested by Ellis (2002). Therefore, after identifying the commonest errors, the analysis has been carried out here following the one suggested by him.

Table 1. Total errors by the students

\begin{tabular}{lll}
\hline Types of errors & Number of errors & Percentage of errors \\
\hline Misordering & 31 & $7 \%$ \\
Overgeneralization & 43 & $10 \%$ \\
Misinformation & 19 & $4 \%$ \\
Grammatical & 338 & $79 \%$ \\
Total & 431 & $100 \%$ \\
\hline
\end{tabular}




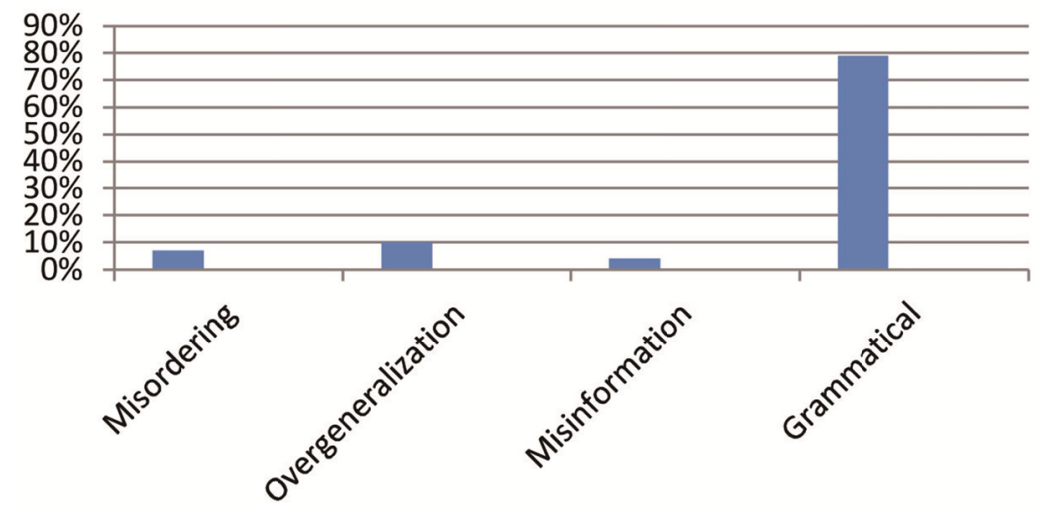

Figure 2. Percentage of students' errors

Table 2. Different types of grammatical errors

\begin{tabular}{lll}
\hline Grammatical errors & Number of errors & Percentage \\
\hline Subject-verb agreement error & 56 & $14 \%$ \\
Article error & 47 & $14 \%$ \\
Verb error & 82 & $24 \%$ \\
Pronoun error & 35 & $10 \%$ \\
Prepositional error & 40 & $12 \%$ \\
Tense error & 78 & $23 \%$ \\
Total grammatical errors & 338 & $100 \%$ \\
\hline
\end{tabular}

\subsubsection{Misordering}

Table 3. Errors caused by misordering

Example: But Bangladeshi people are good not in English.

Most of them are attentive not in English learning.

The correct form of this sentence is "Bangladeshi people are not good in English" and "Most of them are not attentive or inattentive in learning English". To be more sophisticated, the people in Bangladesh do not have good command in English language. As such, the particular learner wrote it with wrong placement of the word- "not". This can be explained in terms of the learners' native language, Bengali, which can also be called L1 interference. In Bengali, typically a sentence structure contains.... "subject + object + verb" in contrast to the structure "subject + verb + object" of English language. Such error demonstrates that learners' knowledge about L1 precedes the sentence construction of L2. The learners intended to translate it directly from his native language (Bengali) to target language (English).

\subsubsection{Overgeneralization}

Table 4. Errors caused by overgeneralization

\begin{tabular}{ll}
\hline Number of Overgeneralization & 43 \\
\hline
\end{tabular}

Examples: Even the university students communicate welly using English.

They should must learn English.

They must have to learn English.

It is unpossible to learn English.......

The first error committed by a particular learner is the adverbial one which the learner made because he 
possessed the knowledge that adding "ly" with an adjective can yield an adverb. Actually, most of the Bangladeshi students, being suggested by their teachers, try to memorize adverb in such way. Ellis (2002) also supports such tendency of the learners stating that "they also over generalize forms they find easy to learn and process" (p. 19). Apart from this, another student wrote a sentence "They should must know English". Similarly, another student wrote "They must have to learn English". In these two sentences, students tried to emphasize on English learning of the students. However, such emphasis led the sentences to overgeneralized ones. In Bengali, often people use some hyperbolic expression. Because of L1 interference, students tend to make overgeneralization in their writing.

\subsubsection{Misinformation}

Table 5. Errors caused by misinformation

Number of misinformation

Examples: People needs English to communicate with foreign people.

English play a vital role in the economic development.

When people goes abroad, they needs English.

The learners made errors concerning subject + verb agreement. The correct form of these sentences the target language are as follows:

People need English to communicate.

English plays a vital role

When people go abroad.

Comparing the erroneous sentences with the correct ones, we can realize that learners have problem in identifying person, i.e., first person, second person and third person, when they write. Since, as mentioned above, they translate from L1 to target language and they lack knowledge about subject + verb agreement, they produce such errors. Thus, they use one form instead of another which results in misinformation.

\subsubsection{Article Errors}

Examples: Errors related to articles are as follows:

The English is an important language.

English is an international language.

It is not possible to learn English within a year.

Below is the correct form of these sentences.

English is an important

English is an international

to learn English within a year.

A noticeable number of students include "The" before English in the beginning of a sentence. The reason behind this is that their teachers taught them to use "the" before English. However, they did not clarify the distinction between the nationality "English" and the language English. It is conspicuous that students lack appropriate knowledge about the usage of articles. The remaining two sentences are drastic example of learners' lack of knowledge. The additional information these two convey is that learners failed to distinguish between English vowels and consonants.

\subsubsection{Verb Errors}

Examples: We have to learning English.

If we know English, it will helping us.

Without learn English, we cannot communicate.

If someone wants to exploring the international arena

The correct forms of these sentences are:

We have to learn English. 
If we know English, it will help us.

Without learning English, we cannot communicate.

If someone wants to explore the international arena.

The errors indicate that students lack the grammatical knowledge which led to the production of deviant structures. According to Ellis (2002), the learners have developed some kinds of rule which are even different from that of the target language.

\subsubsection{Pronoun Errors}

Examples: Bangladeshi people is good not in English. Therefore, he cannot

When people goes abroad, he need.

The correct forms of the wrong sentences produced by the learners are-

People in Bangladesh are not good in English. Therefore, they cannot.

When people go abroad, they need English.

From the aforementioned sentences produced by the students, it becomes conspicuous that students lack substantial knowledge about parts of speech. Therefore, they fail to relate the nouns to their aligned pronoun.

\subsubsection{Prepositional Errors}

Examples: English helps us communicate foreign people.

English is important to communicate other countries.

The correct sentences are:

English helps us to communicate with foreign people.

English is important to communicate in other countries.

Ellis (2002) defined such errors as transfer error. In these sentences, learners attempt to incorporate the sentence construction knowledge of their L1. Prepositional errors occurred because students did not know the appropriate use of it. L1 interference is also responsible for such error.

\subsubsection{Tense Error}

Examples: Nowadays the importance of learning English could not be described in words.

Previously, English is not given importance.

In today's world, people of different countries spoke English as a common language.

When comes to evaluation, the very pertinent question is whether the errors occurred were considered as the local errors or global ones. Since the errors spelled in learners' writing affect the single constituent of a given sentence, it is plausible to identify them as local errors.

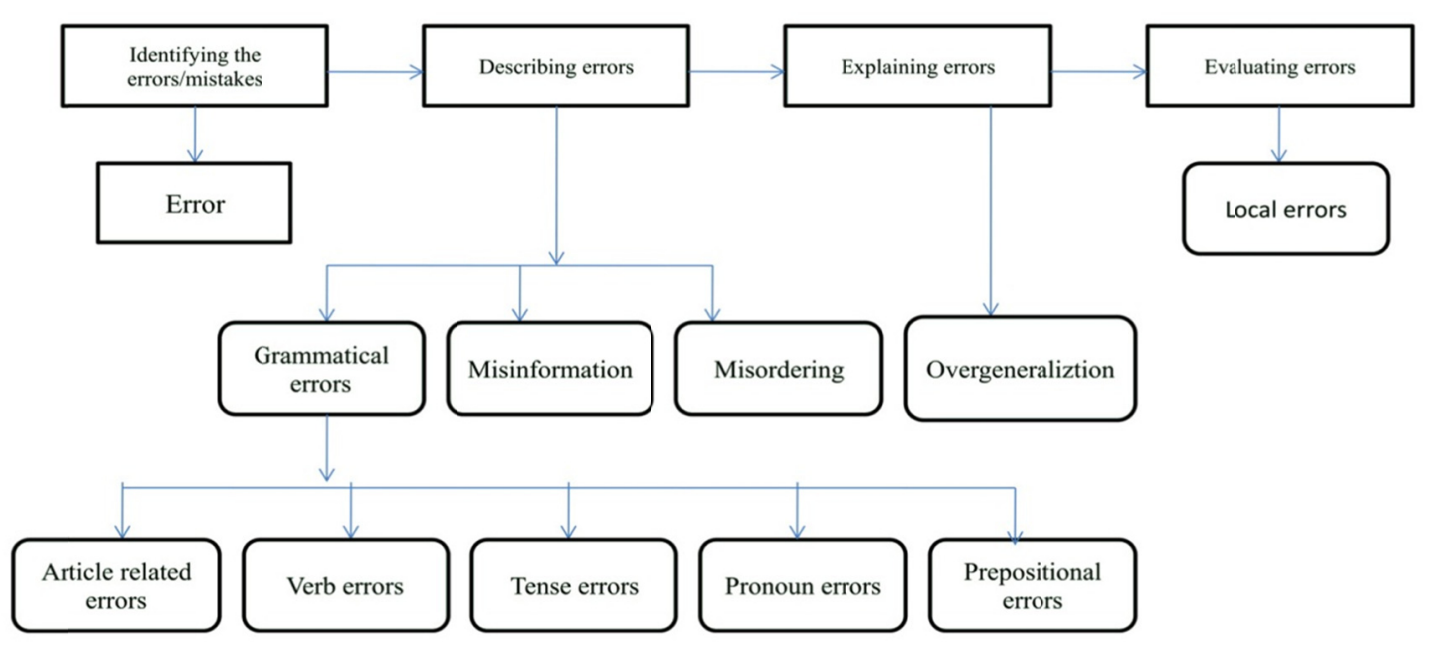

Figure 3. A sketch of Bangladeshi learners' error analysis 


\subsection{Research Question No 2}

\subsubsection{Data Elicited from Student Questionnaire Survey}

Concerning a large amount of data yielded, only the significant findings are reported. Where the data regard statistics, only those of descriptive are stated, since statistical testing finds no difference resulting from the variety in terms of participants' grade level. Depending on the necessity, the interview data has been presented verbatim.

Table 5. Students' perception concerning the teachers' error correction feedback

\begin{tabular}{ll}
\hline Said that teachers marked all errors & $65 \%$ \\
\hline Wanted teachers to mark all errors & $86 \%$ \\
\hline
\end{tabular}

Data elicited from the student questionnaire, as depicted in Table 5, revealed that students concerned the error correction suggested by the teachers. Majority of them (65\%) expressed that underlining the erroneous part, teachers notified them the areas to be corrected. In response to another question, $86 \%$ of them preferred their teachers to identify all their errors. In the interview session, participants expressed that they wanted to be aware of the errors they had made. For instance, one of the participants stated, "I know what errors I make, when the teachers mark them".

Table 6. Students' perception of type of error feedback produced by the teachers

\begin{tabular}{ll}
\hline Said that teachers gave direct feedback on all errors & $46 \%$ \\
\hline Wanted teachers to give direct feedback on all errors & $74 \%$ \\
Wanted teachers to give direct feedback on some errors & $18 \%$ \\
\hline
\end{tabular}

The survey, as presented in Table 6, suggested that students were aware of the teachers' practice. About $46 \%$ of the participants reported, the teachers yielded direct feedback concerning the errors occurred. Most of the participants (74\%) indicated that they wanted their teachers to provide correction for all errors, while only $18 \%$ of them preferred teachers to provide them with some corrections. In other words, students perceived teachers primarily responsible for correcting their errors. In the interview, participants delineated that they wanted their teachers to provide them with correction because such correction they felt more easily rectifiable. "Teacher-directed correction helps me out with easy recovery of my errors" one participant stated. Another participant mentioned, "if teachers discuss the common errors, even after correcting individual, in front of the class, it will be more effective since others can also get aware of the errors."

Table 7. Students' perception of their teacher's use of error codes

\begin{tabular}{lc}
\hline Said that teachers used error codes & $90 \%$ \\
\hline Said they were able to follow over $3 / 4$ of error codes & $42 \%$ \\
Said they were able to follow $1 / 2$ to $2 / 3$ of error codes & $41 \%$ \\
Said they were able to correct over $3 / 4$ of errors based on error codes & $37 \%$ \\
Said they were able to correct $1 / 2$ to $3 / 4$ of errors based on error codes & $43 \%$ \\
Said they wanted teachers to use error codes & $78 \%$ \\
\hline
\end{tabular}

$90 \%$ of them explicated, as Table 7 illustrated, that their teachers used error codes in marking their compositions. However, a number of students admitted that they did not always understand the codes. For instance, $42 \%$ of them said they were able to follow and understand over $3 / 4$ of the codes when correcting errors in their compositions. About $41 \%$ of the students reported that they could follow $1 / 2$ to $3 / 4$ of the codes. Students were also asked if they could correct errors based on the codes. Approximately $37 \%$ of them reported that they were able to correct over $3 / 4$ of the errors, and $43 \%$ of them reported that they could correct $1 / 2$ to $3 / 4$ of the errors. Although students reported that they could not always cope with the codes, the interview data depict that students' preference for error codes were mainly based on the fact that the codes could enable them to understand the types of errors they made. In other words, the codes could make them familiarize with specific types of errors. One of the participants, Sanjit, reported, "If teachers do not use error codes, I will not be aware of the kind of error I commit". Another student, Maqbul, said, When teacher marks the error as tense/verb error 
(T/v/v.t./T(present)/ T(past)/past simple/ tn/tv/vb/past par/vF v 1 v2, e.g., I had (v1) not go (v2)) or article error (Ar/art/A), at that time it becomes easier for me to be notified about my errors". Yet using codes cannot uproot the problem. Some students remarked that since they lacked good command in grammatical rules, they failed to follow the codes. Lee (2004) explicated, "Knowing the codes is one thing, but correcting error is quite another" (p. 297). Another student, Barkat, expressed, "I can understand the errors associated with parts of speech when teacher codifies them. However, I have some issues regarding grammar". One of the participants, Riad, claimed, "Since the class is restricted by specific time, teacher cannot use codes sometime, instead, he underlines the erroneous part using red pen. At that time I realize that the sentence is incorrect, but I do not have cognizance about the type of error".

Table 8. Students' perception of effectiveness of their teacher's error feedback

\begin{tabular}{ll}
\hline Said they thought they were making good progress in writing accuracy & $11 \%$ \\
\hline Said they thought they were making some progress in writing accuracy & $48 \%$ \\
Said they thought they would make the same errors again & $69 \%$ \\
\hline
\end{tabular}

What did the students think about their own progress in writing? Overall, $48 \%$ of the students reported, as depicted in Table 8, that they were making some progress. Only $11 \%$ of the participants thought that they were attaining noticeable progress in terms of grammatical accuracy in writing. When asked if they would make the same errors after the teacher had corrected them. Majority of them $(69 \%)$ answered in affirmative. The interview data elicited several reasons. In particular, they failed to apply the same rule in all situations. This is because of the distinct topics and context of the next composition. Meanwhile, they might forget what they have learnt. One student, Majid, indirectly figured out the demerits of extensive error stating that, "It is difficult for me to handle so many things such as, vocabulary items".

Table 9. Students' perception about the responsibility for error correction

\begin{tabular}{ll}
\hline Said it is mainly the teacher's job to locate and correct errors for students & $48 \%$ \\
\hline Said it is mainly the student's job to locate and correct their own errors & $52 \%$ \\
\hline
\end{tabular}

What did the students think about the responsibility for error correction? Nearly half of them (48\%), in Table 9, perceived that it was their teachers' job to locate and correct their errors for them while $52 \%$ of them hold the belief that the learners should correct their errors. When interviewed, most of the students responded that it was the responsibility of the teachers to correct errors. Only student, Farooq, has been found acclaiming that student should correct their own errors. However, he added that this responsibility seems uninteresting to the learners. Because of the laziness or reluctance, "I sometimes do not like to identify and correct mistakes", he elicited. Two more participants, Masood and Sajib, endorsed this statement and claimed that teacher is the responsible authority for correcting learners' errors. The rationale most of the participants expressed was the teachers' competence in error correction. For example, "I do not feel myself able to locate the mistakes. I am not a good proof reader and thereby, I should leave my write up to the teachers for correction". Therefore, the interview yielded the statement that teachers should be responsible for correcting learners' errors.

\section{Discussion}

From the error analysis, it has been observed that Bangladeshi EFL learners prone to commit grammatical errors mostly. This finding is linear to Kennedy's (2010) study, indicating that grammatical errors are the most frequently committed errors by the learners. Conversely, Sung \& Tsai's (2014) investigation revealed that grammatical errors are rarely made errors by the Chinese EFL learners, although there is substantial difference existing between Chinese grammar and English grammar. In the case of Bangladesh, it should not be the case. For elaboration, the change of verb is prevailed in English language depending on whether the speaker is referring to past, present or future. Likewise, Bengali language also requires the change of verbs to refer to the events taken place in the past, present or future. For example, the sentence in English, I played football yesterday, necessitates the speaker to change the verb from "play" to "played" to refer to the past tense. Likewise, in Bengali, the speaker, putting "yesterday" at the beginning, requires to change verb to refer to the past. Therefore, it is surprising that students' errors are largely associated with verb and tense errors. As such, it needs to be investigated that whether or not instructional shortcoming is liable for committing such errors.

Concerning the survey, the findings of the concurrent study are commensurate with those uncovered in both ESL 
and EFL settings (see Katayama, 2007b; Cathcart \& Olsen, 1976; Chenoweth et al., 1983; McCargar, 1993; Oladejo, 1993; Bang, 1999). For instance, studies carried out by Katayama (2006, 2007a) also illustrate that $92.8 \%$ of the participants exhibit their strong preference for teacher correction. Schulz's (2001) observation also demonstrates Foreign Language (FL) learners' strong urge for error correction. A Bangladeshi study on English teaching in urban schools demonstrates how Bangladeshi learners, dependent on teachers' comprehensive corrective feedbacks, display reluctance in even seriously taking note of teachers' corrections and thus continue to perform the errors repeatedly (Shahed, 1998). The reason behind this lies in students' resentment attitude toward English (they learn English only because it is a part of their curriculum) that has been a result of inconsistent, aimless education policy in Bangladesh (ibid).

Schulz anticipates that "perceptions could be the result of the way FLs are taught or tested (i.e., with predominantly form-focused, discrete-point tests) or both" (p. 255). Learners feel the necessity of being accurate, since it facilitates them to attain a good mark in the examination. It is worth mentioning that vivid examinations have been developed only to test the accuracy of the students in producing correct pieces of language (Edge, 1989). Advocates of error correction oppose comprehensive error feedback concerning the risk of "exhausting teachers and overwhelming students" (Ferris, 2002, p. 50). Thus, Ferris calls for the effective error correction stating, "when it focuses on patterns of error, allowing teachers and students to attend to, say, two or three major types at a time rather than dozens of disparate errors" (p. 50). Study carried out by Lee (2004) suggests that not all the teachers consider the use of error codes as effective. It is expected that notifying the error types can be prompts reinforcing learners' learning. However, Lee concerns that when teachers mark all the errors and code them, an essay written by a student seems containing error codes throughout, which generates the plausible question if this students have the ability to correct this errors.

Students, for the most, demand their errors to be marked comprehensively by teachers. Perhaps, teachers' practices in the classroom precede such expectation and preferences. Lee (2004) divulges that secondary students in Hong Kong also grow such expectation because of their teachers' practices. Cohen \& Cavalcanti (1990) reckon, "learners' expectations and preferences may derive from previous instructional experiences, experiences that may not necessarily beneficial for the development of writing" (p. 173). Lee (2004) elaborate that if student errors are corrected by the teachers, certainly, students possess belief that teachers are solely responsible to correct their errors. In the case of Bangladesh, English teacher tend to circle the erroneous part of pupils' writing by using red per. Sometimes teachers, after circling, write the correct version in the script. Learners have been introduced to such correction from the very beginning of their schooling. Consequently, they expect their teachers to mark their errors.

In such context, this current research would help ELT experts, academics and educational policymakers get a focused overview of the nature of student errors along with learners' perception - which is innovative in the domain of error analysis in Bangladesh.

This study is the categorical illustration of the commonest errors committed by the Bangladeshi learners. Mostly, as depicted, the errors derived from misordering, overgeneralization, misinformation and grammar such as, article, preposition, pronoun, verb and tense. The findings of the study can serve the scaffold for the teachers, since addressing these errors and correcting them become their first concern. Caused sometimes due to the L1 interference and inadequate knowledge about grammatical rules, these errors debilitate the quality of students' writing. As aforementioned, EFL learners in Bangladesh are generally introduced to all the grammatical rules by grade 8 . Therefore, it is expected that they are equipped with the rules, and thereby, able to produce correct piece of writing. However, the results of the study exhibit that learners were still struggling to produce even a sentence using simple present tense. Another issue slackening students' attainment of accuracy is the time and exposure allocated to learning English. In the beginning, it was mentioned that only 240 minutes (4 hours) is generally allocated weekly to learn English in the secondary level while other subjects taught in Bengali encompass the remaining hours of their schooling. Therefore, with difference prevailed in Bengali and English in terms of the sentence construction, students prone to spell erroneous sentences.

The findings of this study suggest that teachers should bring change in their classroom practices. In the teachers' professional development programs, session should be conducted concerning how comprehensive marking and correction of errors can dismantle students and teachers, what has been dubbed as "student frustration and teacher burnout" Ferris (2002, as cited in Lee 2004, p. 303). However, student expectation can be changed by teachers, reversing their classroom practice. Lee (2004), in this regard, recommends that teachers should abdicate their get-the-job-done attitude. By linking, as explicated, the pre- and post- writing grammar instruction, teachers can assist students. For instance, teachers can mention about which tense be used for particular piece of writing. If an essay to be written entitling "A journey by boat", teachers should initially tell the students to use 
"simple past tense" and explain why they have to use it. On top of that, the size of the class (Karim, Mohamed, Rahman \& Haque, 2017) is a major factor challenging the correction of individual errors. Ge (2011) also reports the same problem associated with the writing classes in Taiwan, mentioning the fact that teachers tend to spend almost all the time lecturing about writing skills and evaluating students' writing by providing teachers' feedback, provided the large class size which requires teachers to consume most of the class-time for providing corrections on individual students' writing assignments (Shintani et al., 2014). Therefore, to reduce the time spent for teachers' such activity, Kaufman \& Schunn (2011) and Shintani et al. (2014) suggest online peer feedback and direct corrective feedback via the use of technological tools, given their proven role to provide higher quality writing instruction. Lin \& Griffith (2014), in other word, explicate that facilitated by synchronous and asynchronous computer-mediated communication (CMC) features to exchange ideas or fix problems for better writing quality, the use of online technologies is a pedagogical approach. English in Action (EIA), according to Karim, Mohamed, \& Rahman (2017), the last teacher training program incorporating Information and Communication Technologies (ICTs), should have accounted online peer feedback and direct corrective feedback via the use of technological tools, which will substantially reduce the overwhelming pressure, yielded from generating error corrections, of the teachers.

The current study incorporates error analysis of the students in Bangladesh. However, acknowledging the significance of student variables in error correction research was not the scope of this study. Further research, therefore, would do in-depth exploration as to how the student factors influence teachers' error correction and students' ability to learn from it. Learners characteristics such as, proficiency, motivation, attitudes and beliefs provide worthy avenues for future research.

\section{Acknowledgments}

The school of Educational Studies, USM provided the authors with financial aid to conduct the study. The first author thoroughly contributed to the development of the manuscript. The second and third authors played a supervisory role throughout. The first, fourth, fifth and sixth author were instrumental concerning the data collection process. The first author carried out data analysis and drew conclusion. I would like to pay my heartfelt gratitude to the school teachers and students who have been cooperative throughout the process.

\section{References}

Ali, M., \& Walker, A. L. (2014). "Bogged down" ELT in Bangladesh: Problems and policy. English Today, 30(02), 33-38. https://doi.org/10.1017/S0266078414000108

Bang, Y. J. (1999). Reactions of EFL Students to Oral Error Correction. Journal of Pan-Pacific Association of Applied Linguistics, 3, 39-51.

Bitchener, J. (2008). Evidence in support of written corrective feedback. Journal of Second Language Writing, 17(2), 102-118. https://doi.org/10.1016/j.jslw.2007.11.004

Cathcart, R., \& Olsen, J. E. W. B. (1976). Teachers' and students' preferences for correction of classroom conversation errors. On Tesol, 76, 41-53.

Chenoweth, N. A., Day, R. R., Chun, A. E., \& Luppescu, S. (1983). Attitudes and preferences of ESL students to error correction. Studies in Second Language Acquisition, 6(1), 79-87. https://doi.org/10.1017/S0272263100000310

Chowdhury, R., \& Kabir, A. H. (2014). Language wars: English education policy and practice in Bangladesh. Multilingual Education, 4(1), 1-16. https://doi.org/10.1186/s13616-014-0021-2

Cohen, A. D., \& Cavalcanti, M. C. (1990). Feedback on compositions: Teacher and student verbal reports. Second Language Writing: Research Insights for the Classroom, 155-177. https://doi.org/10.1017/CBO9781139524551.015

Cohen, A. D., \& Robbins, M. (1976). Toward assessing interlanguage performance: The relationship between selected errors, learners' characteristics, and learners' explanations. Language Learning, 26(1), 45-66. https://doi.org/10.1111/j.1467-1770.1976.tb00259.x

Corder, S. P. (1967). The significance of learner's errors. IRAL-International Review of Applied Linguistics in Language Teaching, 5(1-4), 161-170. https://doi.org/10.1515/iral.1967.5.1-4.161

Corder, S. P. (1974). Error analysis. The Edinburgh Course in Applied Linguistics, 3, 122-131.

Darus, S., \& Ching, K. H. (2009). Common errors in written English essays of form one Chinese students: A case study. European Journal of Social Sciences, 10(2), 242-253. 
Dulay, H., Burt, M., \& Krashen, S. (1982). Language Two. Oxford: Oxford University Press.

Edge, J. (1989). Mistakes and correction. London, New York: Longman.

Ellis, R. (2002). Second Language Acquisition. Oxford: Oxford University Press.

Ellis, R. (2009). Corrective feedback and teacher development. L2 Journal, 1(1), 3-18. Retrieved from http://repositories.cdlib.org/uccllt/12/vol1/iss1/art2/

Ferris, D. (2011). Treatment of error in second language student writing. Michigan: University of Michigan Press. https://doi.org/10.3998/mpub.2173290

Ferris, D. R. (2010). Second language writing research and written corrective feedback in SLA: Intersections and practical applications. Studies in Second Language Acquisition, 32(2), 181-201. https://doi.org/10.1017/S0272263109990490

Ferris, D. R., Chaney, S. J., Komura, K., Roberts, B. J., \& McKee, S. (2000, March). Perspectives, problems, and practices in treating written error. Colloquium presented at International TESOL Convention, Vancouver, BC.

Gay, L. R., Mills, G. E., \& Airasian, P. W. (2011). Educational research: Competencies for analysis and applications. White plains, NY: Pearson Higher Ed.

Ge, Z. G. (2011). Exploring e-learners' perceptions of net-based peer-reviewed English writing. International Journal of Computer-Supported Collaborative Learning, 6(1), 75-91. https://doi.org/10.1007/s11412-010-9103-7

Granger, S., Dagneaux, E., Meunier, F., \& Paquot, M. (2002). The International Corpus of Learner English. Handbook and CD-ROM. Louvain-la-Neuve: Presses Universitaires de Louvain.

Hamid, M. O., \& Honan, E. (2012). Communicative English in the primary classroom: Implications for English-in-education policy and practice in Bangladesh. Language, Culture and Curriculum, 25(2), 139-156. https://doi.org/10.1080/07908318.2012.678854

Hasan, M. K., \& Akhand, M. M. (2010). Approaches to writing in EFL/ESL context: Balancing product and process in writing class at tertiary level. Journal of NELTA, 15(1-2), 77-88.

Hedgcock, J., \& Lefkowitz, N. (1994). Feedback on feedback: Assessing learner receptivity to teacher response in L2 composing. Journal of Second Language Writing, 3(2), 141-163. https://doi.org/10.1016/1060-3743(94)90012-4

Hendrickson, J. M. (1978). Error correction in foreign language teaching: Recent theory, research, and practice. The Modern Language Journal, 62(8), 387-398.

Karim, A., Mohamed, A. R., \& Rahman, M. M. (2017). EIA-A Teacher Education Project in Bangladesh: An Analysis from Diversified Perspectives. International Journal of Instruction, 10(4), 51-66. https://doi.org/10.12973/iji.2017.1044a

Karim, A., Mohamed, A. R., Rahman, M. M., \& Haque, M. H. (2017). Teachers' dilemma bog down CLT in EFL contexts: A discussion on EFL teachers' beliefs and sources. IOSR Journal of Humanities and Social Science (IOSR-JHSS), 22(4), 112-120. https://doi.org/10.9790/0837-220405112120

Katayama, A. (2006). Perceptions of JFL students toward correction of oral errors. In JALT2005 Conference Proceedings (pp. 1248-1264). Tokyo: JALT.

Katayama, A. (2007a). Japanese EFL students' preferences toward correction of classroom oral errors. Asian EFL Journal, 9(4), 289-305.

Katayama, A. (2007b). Students' perceptions of oral error correction. Japanese Language and Literature, 41(1), 61-92.

Kaufman, J. H., \& Schunn, C. D. (2011). Students' perceptions about peer assessment for writing: their origin and impact on revision work. Instructional Science, 39(3), 387-406. https://doi.org/10.1007/s11251-010-9133-6

Kennedy, S. (2010). Corrective feedback for learners of varied proficiency levels: A teacher's choices. TESL Canada Journal, 27(2), 31. https://doi.org/10.18806/tesl.v27i2.1054

Kranshen, S. D. (1985). The input hypothesis: Issues and implication. London: Longman.

Krashen, S. D. (1981). Second language acquisition and second language learning. Oxford: Oxford University 
Press.

Krashen, S. D. (1987). Principles and practice in second language acquisition (pp. 1982-1982). New York: Pergamon Press.

Lee, I. (2004). Error correction in L2 secondary writing classrooms: The case of Hong Kong. Journal of Second Language Writing, 13(4), 285-312. https://doi.org/10.1016/j.jslw.2004.08.001

Leki, I. (1991). The preferences of ESL students for error correction in college-level writing classes. Foreign Language Annals, 24(3), 203-218. https://doi.org/10.1111/j.1944-9720.1991.tb00464.x

Lin, S. M., \& Griffith, P. (2014). Impacts of online technology use in second language writing: A review of the literature. Reading Improvement, 51(3), 303-312.

McCargar, D. F. (1993). Teacher and student role expectations: Cross-cultural differences and implications. The Modern Language Journal, 77(2), 192-207. https://doi.org/10.1111/j.1540-4781.1993.tb01963.x

Nunan, D., \& Carter, R. (Eds.). (2001). The Cambridge guide to teaching English to speakers of other languages. Ernst Klett Sprachen.

Oladejo, J. A. (1993). Error correction in ESL: Learner's preferences. TESL Canada Journal, 10(2), 71-89. https://doi.org/10.18806/tesl.v10i2.619

Ommaggio, A. C. (1986). Teaching language in context: proficiency-oriented instruction. The Modern Language Journal, 17, 286-479. Boston: Heinle and Heinle publishers.

Polio, C., \& Fleck, C. (1998). "If I only had more time:” ESL learners' changes in linguistic accuracy on essay revisions. Journal of Second Language Writing, $4(1)$, 43-68. https://doi.org/10.1016/S1060-3743(98)90005-4

Radecki, P. M., \& Swales, J. M. (1988). ESL student reaction to written comments on their written work. System, 16(3), 355-365. https://doi.org/10.1016/0346-251X(88)90078-4

Robb, T., Ross, S., \& Shortreed, I. (1986). Salience of feedback on error and its effect on EFL writing quality. TESOL Quarterly, 20(1), 83-96. https://doi.org/10.2307/3586390

Schulz, R. A. (2001). Cultural differences in student and teacher perceptions concerning the role of grammar instruction and corrective feedback: USA-Colombia. The Modern Language Journal, 85(2), 244-258. https://doi.org/10.1111/0026-7902.00107

Shahed, F. H. (1998). English in School Education: Focus on Urban Schools (Unpublished M.Phil. dissertation). Jawaharlal Nehru University, New Delhi, India.

Sheen, Y. (2011). Corrective feedback, individual differences and second language learning. Berlin, Germany: Springer. https://doi.org/10.1007/978-94-007-0548-7

Sinha, B. S. (1997). Learners' errors, Their Significance in L2 Learning and The Role of Correction. The Dhaka University Studies, 54(2), 145-157.

Sung, K. Y., \& Tsai, H. M. (2014). Exploring Student Errors, Teachers' Corrective Feedback (CF), Learner Uptake and Repair, and Learners' Preferences of CF. The Journal of Language Teaching and Learning, 4(1), $37-54$.

Truscott, J. (1996). The case against grammar correction in L2 writing classes. Language Learning, 46(2), 327-369. https://doi.org/10.1111/j.1467-1770.1996.tb01238.x

Truscott, J. (1996). The case against grammar correction in L2 writing classes. Language Learning, 46(2), $327-369$. https://doi.org/10.1111/j.1467-1770.1996.tb01238.x

Wang, X. (2017). The Effects of Corrective Feedback on Chinese Learners' Writing Accuracy: A Quantitative Analysis in an EFL Context. World Journal of Education, 7(2), 74-88. https://doi.org/10.5430/wje.v7n2p74

\section{Appendix A}

\section{Student Questionnaire}

\section{A.1. Marking of English writings}

This questionnaire aims to find out your views about how English compositions should be marked. Please answer the questions with reference to how your present English teacher marks your writings in this academic year. All your answers will be treated confidentially. 
Please Tick the appropriate answers

- Which of the following is true?

- My English teacher underlines/circles all my errors.

- My English teacher underlines/circles some of my errors.

- My English teacher does not underline/circle any of my errors.

- I have no idea about the above.

If your answer of the question 1 is "B", answer question 2. If your answer is "A", "C", or "D", go to question 3.

- Before or after marking your writings, does your teacher tell you what error types (e.g., verbs, pronoun, tense) s/he has selected to mark?

- Yes

- No

- Which of the following do you like best?

- My English teacher underlines/Circles all of my errors.

- My English teacher underlines/Circles some of my errors.

- My English teacher does not underline/Circle any of my errors.

- Which of the following is true?

- My English teacher corrects all errors for me.

- My English teacher corrects some errors for me.

- My English teacher does not correct any error for me.

- I have no idea about the above.

- Which of the following do you like best?

- My English teacher corrects all errors for me.

- My English teacher corrects some errors for me.

- My English teacher does not correct any error for me.

- Does your English teacher use a correction code in marking your compositions (i.e., using symbols like v, Adj, tetc.)?

- Yes

- No

\section{If your answer to question 6 is "Yes", answer question 7 and 8 . If your answer is "No", go to question 9.}

- What percentage of your English teacher's marking symbols (e.g., $\mathrm{t} / \mathrm{v} / \mathrm{adv}$ ) are you able to follow and understand when you are correcting errors in your compositions?

- $76-100 \%$

- $51-75 \%$

- $26-50 \%$

- $0-25 \%$

- What percentage of errors you are able to correct with the help of your English teacher's marking symbols $(\mathrm{t} / \mathrm{v} / \mathrm{adv})$ ?

- $76-100 \%$

- $51-75 \%$

- $26-50 \%$

- $0-25 \%$

- After your teacher has corrected the errors in your writings, do you think you will make the same errors again? 
- Yes

- No

- Do you want your English teacher to use a correction code (using symbol like $\mathrm{t} / \mathrm{v} / \mathrm{adv}$ ) in marking your writing?

- Yes

- No

- Which of the following is true?

- In this academic year, I am making good progress in grammatical accuracy in writing.

- In this academic year, I am making some progress in grammatical accuracy in writing.

- In this academic year, I am making little progress in grammatical accuracy in writing.

- In this academic year, I am making no progress in grammatical accuracy in writing.

- Which of the following do you agree with?

- It is mainly the teacher's job to locate and correct errors for students.

- It is mainly the student's job to locate and correct their own errors.

\section{Appendix B}

Grammatical Syllabi for grade 7, 8, 9 and 10

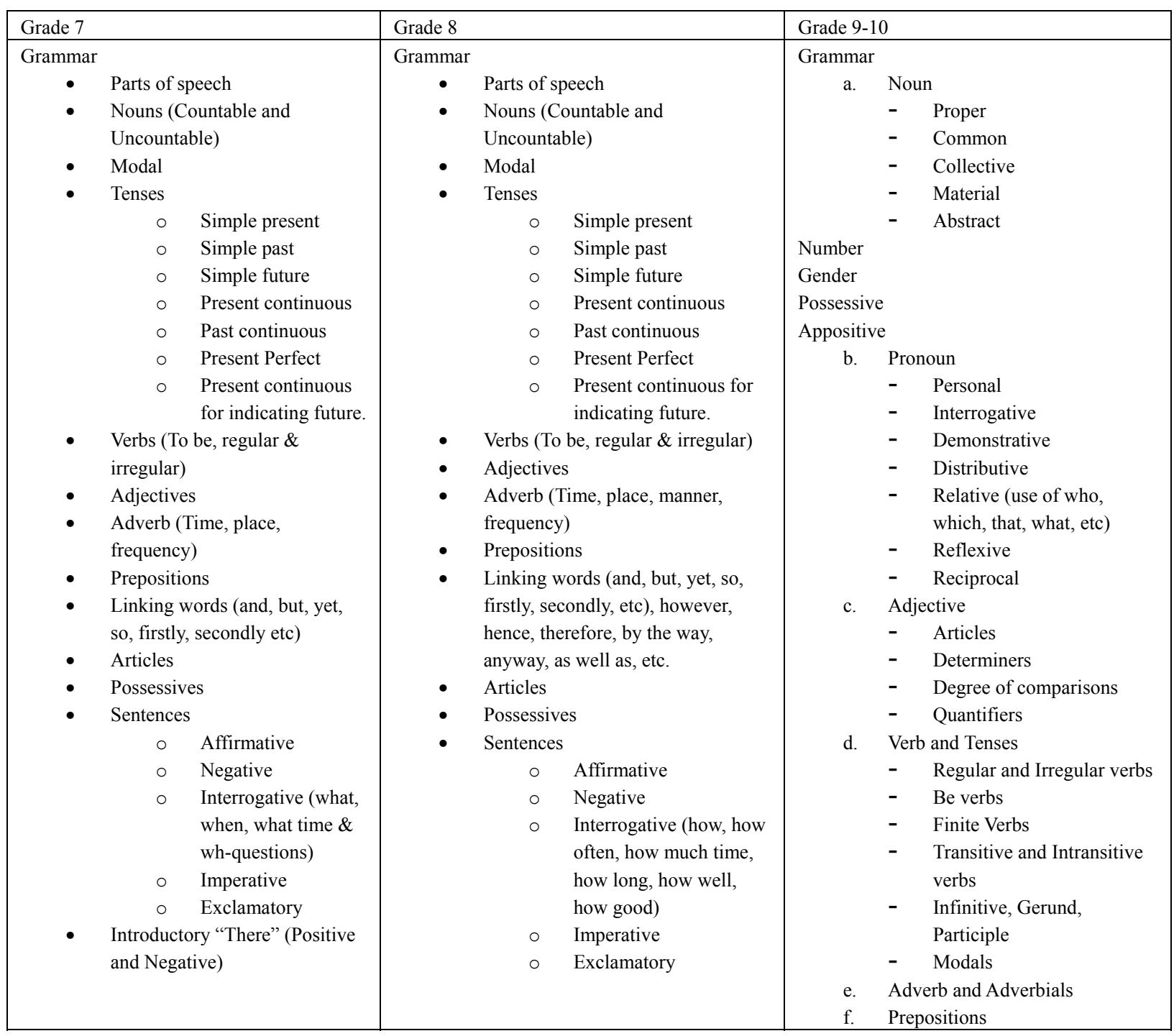




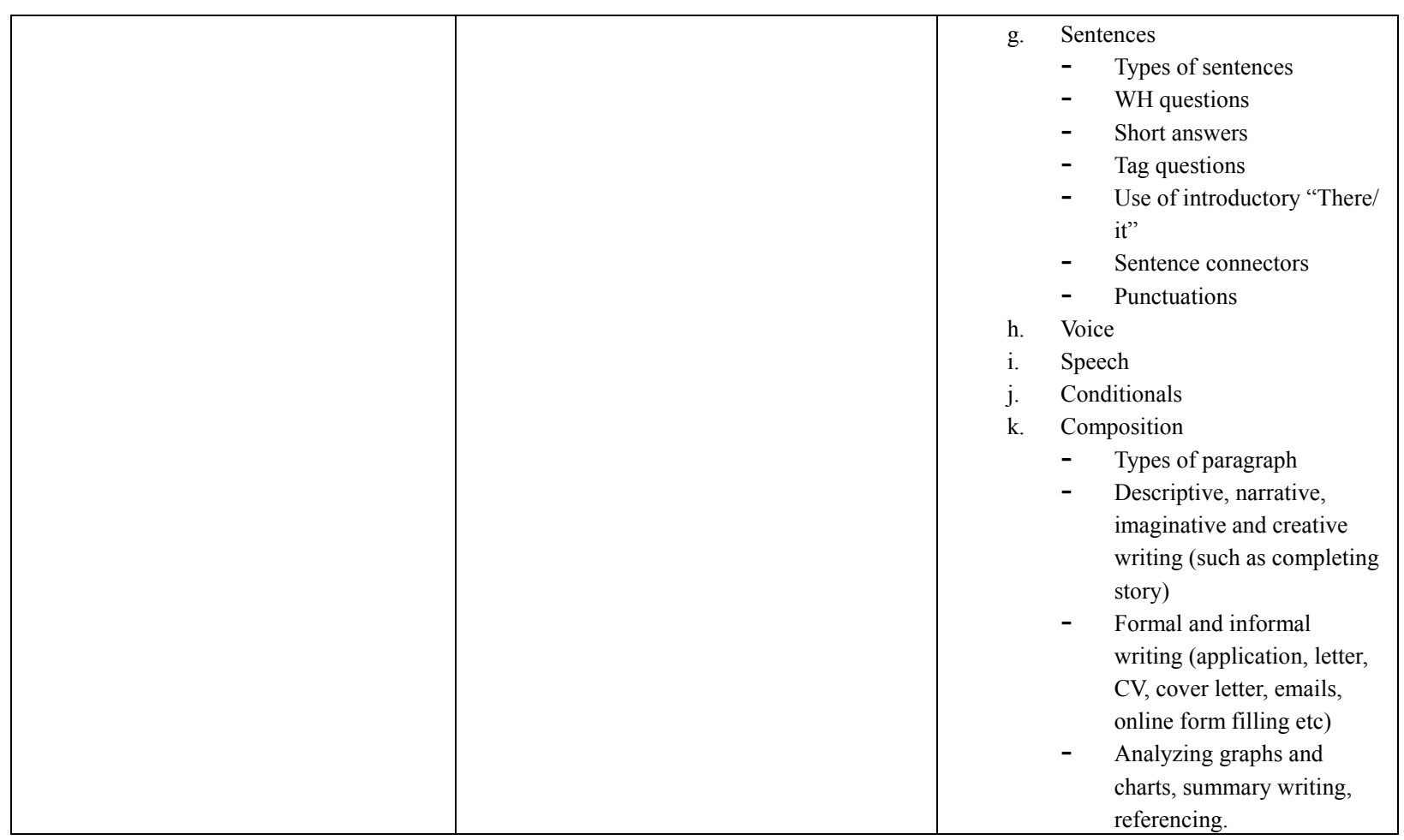

\section{Copyrights}

Copyright for this article is retained by the author(s), with first publication rights granted to the journal.

This is an open-access article distributed under the terms and conditions of the Creative Commons Attribution license (http://creativecommons.org/licenses/by/4.0/). 